\title{
INTRODUCTION: INSTABILITY, ANTI-POLITICS, AND FRUSTRATED ASPIRATIONS FOR CHANGE
}

\author{
Mark Donovan and Paolo Onofri
}

It is difficult to tell a story pretending not to know how it ends. This volume is concerned with the political and politico-economic events that took place in Italy during the course of 2007, but in reality it is implicitly the story of an aborted legislature, the fifteenth in the Republic's history, which began in April 2006 and ended prematurely in January 2008. Perhaps in anticipation of this outcome, the year 2007 was permeated by a sense of deep political malaise. The government of Romano Prodi, despite having been in office since only May 2006, and despite its reasonably effective management of the economy, was weak and unpopular. Its frailty was rooted, most immediately, in the election outcome, which gave it a majority of just two in the Senate, and that outcome in turn resulted in large part from the effects of the electoral system reform introduced by the center-right government in December 2005. The purpose of that reform - or counter-reform, as some prefer to call it-was to minimize the scale of the government's expected defeat or, reversing the perspective, to render the center-left's victory as marginal as possible.

In any event, the expectation that the government could not survive long was strong from the outset, and it was scarcely a surprise when Prime Minister Prodi tendered his resignation on 21 February 2007, having lost an important foreign policy vote in the Senate (see Walston's chapter in this volume). While the president of the Republic,

Notes for this section begin on page 49 . 
Giorgio Napolitano, refused to accept Prodi's resignation without a parliamentary vote, requiring Prodi to return and seek, successfully, a vote of confidence, the public was nevertheless treated to a full-scale spectacle of governmental weakness and division. The refusal to back the government by two of the more intransigent left-wing senatorsone from each of the two Communist parties within Prodi's nine-party coalition-gave the opposition significant ammunition to claim that the government was dependent on extremists.

\section{The Strategy of the Prodi Government}

Despite the government's political frailty and the possibly limited time at its disposal, Prodi, Tommaso Padoa-Schioppa (minister of finance), and Pier Luigi Bersani (minister for economic development) had a very precise medium-term strategy in mind with regard to economic policy. Past experience suggested that, regardless of who is in government, it is always the current government that is perceived by the public as being responsible for everything that does not work-even if problems have been inherited from previous (often long previous) governments. The first step of the strategy, then, was to rupture this connection by carrying out a radical and surprising initiative at the very outset of the government's life. This clear break with the past was a sort of captatio benevolentiae (a rhetorical device used to secure the goodwill of an audience-in this case, the public). The first so-called lenzuolata, a set of liberalization measures put forward by Bersani in July 2006, was a surprise even for the other members of the government. Its impact on public opinion was very positive, and this allowed the government to recover from the negative reaction to the very large number of ministers and undersecretaries it had appointed upon taking office. It showed that the government really did want "to bring change," even if the requirements of coalition stability had necessitated the formation of a bloated cabinet structure.

The second step of the strategy was to use "the stick" of budget consolidation through the financial law for 2007, the first budget year of the legislature, in order to bring the deficit back onto a trajectory consistent with achieving a zero deficit in 2010 (as previously agreed upon with the EU). This would make it possible once again to start reducing the public debt to GDP ratio. In fact, both downward trends had been interrupted by the previous government. The third step of the strategy was to have been to provide "the carrot": on the one hand, the redistribution of the fiscal burden and, on the other, the enlargement of the welfare state provision. 
Public opinion polls showed that something went wrong with the plan from the very first step, however. From a technical point of view, some measures on real estate trading had to be changed, but more relevant was the retreat in the showdown with the taxi drivers (see Boitani's chapter). Nonetheless, both general retail trade and the retail distribution of some medicines were further liberalized, and competition did increase between professionals, between insurance companies, and between commercial banks-all to the benefit of citizen consumers.

The opposition's success in organizing protests by shopkeepers, pharmacists, and different categories of professionals was made easier by the 2007 financial law: the income tax increase was imposed only on middle- and higher-income brackets, while the fight against tax evasion was directed mainly at the self-employed. These measures were part of the second step of the strategy-the stick. The problem was not only a matter of tax increases, for taxes were also reduced, mainly on labor costs and on households with children. However, these cuts were passed amid such intense debate among the parties of the parliamentary majority that public opinion was disoriented and lost sight of the substance of the measures that were going to be enacted. Nor was the redistribution of the tax burden so clear-cut in the end due to its limited extent, an outcome resulting from both the constraints on the budget and the dispersion of the gains across many small measures instead of their concentration in one large one (see Baldini and Bosi's chapter).

\section{Fifteen Months against a Headwind}

This is the story of the second half of 2006, but it is at the root of the "half-empty glass" attitude according to which public opinion viewed the actions of the government in 2007. It did not matter that the economy, at least in the first half of the year, grew at a rate close to 2 percent (and 1.5 percent on average), nor that unemployment fell to 5.9 percent, the lowest level since the beginning of the 1990s. It did not matter that, from an institutional point of view, 2007 was the first year of the full working of the renewed Bank of Italy (see Quaglia's chapter), with its new leadership role in the restructuring of the Italian banking system, and that a second set of liberalization measures was enacted in the spring. Nor did it matter that the success in the reduction of tax evasion allowed the government to give part of the recovered revenue to workers in the spring and autumn-again, it was too many small sums for too many people. It did not matter that in the autumn the financial law included the smoothing of the so-called 
scalone (sudden, large increase) in the age for seniority pensions and the reform of unemployment insurance, nor that the public deficit was lower than the government target (1.9 percent of GDP, compared with 3.4 percent in 2006). This came about not only because government revenue was higher than expected, but also because current expenditures were restrained, in spite of the ever-increasing expenditure on health (see Bordignon and Turati's chapter) and increased interest payments on the public debt, due to higher interest rates.

The half-empty glass perspective also resulted from a number of reforms that were presented to Parliament but did not progress further because of contrasting opinions within the government majority. These included public local services (see Boitani, again), the reorganization of the market supervisory authorities, and reform of the national television system and of the public broadcasting company (RAI). One could argue that these are not subjects on which public opinion is very sensitive. Yet other outcomes that did not happen refer mainly to innovative reforms in the welfare state institutions, that is, matters with direct significance for citizens: universal family allowances for children, long-term care institutions, and the security parts of the flex-security approach to the labor market, notwithstanding that the flexibility section had already been implemented by previous governments, a disparity in implementation that had often happened in the past.

From a strictly economic standpoint, the government could have coped with these deficiencies and bought enough time to win consensus with the third step, which was planned for 2008. However, in the medium term, the degree of inequality in income distribution worsened, and the international oil and agricultural price shocks and rising food costs brought about a further deterioration in the standard of living.

\section{The Rising Tide of Anti-politics}

In a longer-term perspective, the government's unpopularity resulted from the interaction of multiple causes, not only economic ones, and found its deep structural roots in the political sphere. In part, its own mistakes were to blame, along with its heterogeneity and the often highly public infighting resulting from this, not least over prominent ethical issues such as the rights of unmarried couples (see Ceccarini's chapter). However, beyond these contingent reasons for public dissatisfaction lay the predisposition of the public to find government wanting. The perception of weakness and inadequacy was fueled, moreover, by the opposition's relentlessly hostile campaign against the government, starting with the election result itself. Silvio Berlusconi 
consistently and repeatedly challenged the legality of the electoral outcome and, hence, the parliamentary basis of the government's legitimacy. Simultaneously, and with growing emphasis in 2007, he challenged the popular legitimacy of the government, given its poor poll ratings and, after the May local elections (see McDonnell's chapter), its poor electoral performance.

It mattered little that in September the Senate-which constituted the government's Achilles' heel, in parliamentary terms-confirmed the full legitimacy of the April 2006 vote; nor that Berlusconi's two governments in the preceding legislature (2001-2006) had themselves suffered a string of electoral defeats at the sub-national level; nor that government unpopularity is a commonplace, even in a parliamentary democracy. The public was ready to hear that the government was illegitimate and incompetent because anti-government sentiment has been a staple of Italian political culture. Public discontent is actually a deeper phenomenon than mere dissatisfaction with the government-it is systemic. Thus, while, antipolitical sentiment has always been a significant background feature of Italian politics, ${ }^{1}$ it is more prominent at times of great political stress, such as during the crisis of the early 1990 s. $^{2}$ Arguably, such sentiment became particularly prominent in 2007, and it did so, one can suggest, not only for the reasons indicated, but also because repeated disappointment over the progress of the "transition" to the "Second Republic" created a mood that a populist political mobilizer like Berlusconi, now that he was once again in the opposition, could ably exploit. Of considerable assistance to the media-cum-political entrepreneur in this enterprise was Beppe Grillo, a comic actor turned political satirist and activist, notwithstanding the fact that Berlusconi's disproportionate influence over television and the press has itself been one of Grillo's major targets.

During the course of 2007, Grillo became a political phenomenon in his own right, but the year also saw at least two major political initiatives unfold, whose purpose was to combat the growth of anti-political sentiment by reinforcing the political system. First was the referendum campaign for electoral reform, which was intended to draw attention to the inadequacy of the existing electoral system as much as actually to change it via the referendum instrument, which is technically severely limited in what it can do (see Baldini and Bosi's chapter). Second was the creation on the center-left of a new party, the Democratic Party, which unified the two largest and most moderate parties and expressed the intention of providing strong and cohesive government without the need for "coerced" and non-cohesive alliances (see Lazar's chapter). The ambition was great, even if the party itself was less than entirely unified and was entirely unlikely to be able to win a majority of the vote on its own. One must add a third and at least equally ambiguous 
initiative to this list: the declaration by Berlusconi of the formation of a new party, the People of Freedom. While this action was intended to create a more unified center-right, and hence a more effective government were it re-elected, it developed out of Berlusconi's populist campaign against the government. Brilliantly exploiting the opportunity presented by the formation of the Democratic Party and the government's weakness, he sought to force his allies to join his enterprise (see Donovan's chapter). Its genesis, then, was fraught with ambiguity, and its future trajectory with uncertainty.

\section{The Deeper Roots of Anti-political Sentiment and the Beppe Grillo Phenomenon}

The structural opportunity for mobilizing anti-political and especially anti-party sentiment was rooted in the chronic-that is, long-termdissatisfaction of Italians with their political system. However, one must be careful here to distinguish between the "ideological" dissatisfaction with the system typical of the ideologically polarized polity of the 1950s-1960s and the more pragmatic and "centrist" dissatisfaction of later years, which expressed antipathy to the debasement of democratic politics in Italy rather than with democratic politics as such. ${ }^{3}$ It is arguable, furthermore, that the multifaceted political crisis of 1993-1994 had brought the promise of betterment, yet had been followed by a series of disappointments, notwithstanding some important governmental successes, most notably in the management of public finances. Thus, focusing on the disillusionments-and not overlooking that in a polity still polarized, if now between supporters and opponents of Berlusconi, many would welcome each of the political defeats that created this climate-we can identify the following points. First, Berlusconi's first government of 1994, the first of the supposed Second Republic, lasted less than a year. Second, the first Prodi government of 1996 lasted only two and a half years. Third, while Berlusconi's second and third governments lasted five consecutive years (2001-2006), selfinterest and internal conflict resulted in the neglect of the economy and the long, drawn-out gestation of a controversial constitutional reform whose eventual content was widely regarded as self-contradictory and which was rejected by referendum in June 2006.

The second Prodi government was, as outlined above, apparently, and metaphorically speaking, rubbing salt into the wound. Thus, quite apart from its economic and welfare policy weaknesses and failures, its popularity suffered a mortal blow in 2006 when a largescale amnesty-which had in fact been approved by the legislature 
independently of the government, but for which the government was blamed-released thousands of prisoners, many of whom subsequently committed further crimes, the most serious of which the news media were very keen to report. Issues of public order, not least local government reactions to specific problems, particularly by center-left administrations, were thus at the forefront of political attention throughout the year (see Sartori's chapter).

The specific discontents of 2006-2007 took place, moreover, against a background in which the Second Republic seemed to be going into reverse. Already the electoral reform of 2005 had reinforced the principle of proportional representation (PR), whereas the putative Second Republic was identified with majoritarianism. A confusing parliamentary debate on yet more electoral reforms that dragged on throughout 2007 at times appeared likely to reinstate PR even more fully. Since this debate sought to pre-empt the referendum initiative brought by frustrated reformers, the motives of the political elite were highly suspect. The referendum would result in rewarding a seats bonus to a single list, rather than an electoral alliance, thus encouraging parties to aggregate while undermining their separate identities, something that many party leaders strongly opposed. The possibility that PR might be restored more fully suggested that the entire transition might be collapsing into a return to the past, even if PR could in fact both sharply reduce the number of parties in the system and even, perhaps, maintain a form of bipolarism. ${ }^{4}$ In any case, by the end of 2007, the electorate was so disillusioned that there were indications that the crisis of Italy's political institutions was encouraging doubts about the absolute value of democracy itself among a significant minority of the population. Thus, a poll in late November showed that nearly one-third of the voters either indicated indifference between democracy and authoritarianism (17.2 percent) or preferred an authoritarian regime to a democratic one in some circumstances (14.6 percent). ${ }^{5}$

Still, one should not overlook that those same polls confirmed that over two-thirds of Italians support democracy-despite the spectacle being made of it in their country. Moreover, placed in a comparative context, much of the data on Italy is not entirely remarkable. While Eurobarometer data from December 2006 showed that only 17 percent of Italians had trust in political parties, the data also revealed that the European average was just 20 percent and that the figure for the UK was only 18 percent. Similarly, the proportion of the public expressing a lack of trust in the triad of parties, Parliament, and government was 68 percent in Italy, but the figure was 66 percent in Germany and 63 percent in the UK and France. ${ }^{6}$ So it is important to consider further the nature of the anti-politics that became so significant in 2007. 
The same November polls also showed considerable public sympathy for Grillo, particularly among younger population cohorts, while a mid-December poll identified him as the second most positively evaluated person from a list of 19 otherwise strictly political figures. ${ }^{7}$ A public celebrity for 30 years, Grillo had been effectively banned from television 20 years ago due to his biting satire of corruption and the then Italian Socialist Party. He turned to touring the country and, in October 2005, was identified by Time magazine as one of Europe's 37 "heroes" for challenging "government and corporate malfeasance." In the same year, his new blog (Weblog) won Il Sole 24 Ore's WWW prize as the best Italian Web site for "news and information." At the end of 2007, his site was provisionally listed at the top of the same WWW prize category for the year, while on the "all categories" prize list, it dropped to sixth place, again provisionally, following Google, Wikipedia, and three Italian sites. ${ }^{9}$ Grillo's move into the "blogosphere" has been a major political development, and by 2007 his activism had reached new heights. His blog is now consistently reported as being the most active non-commercial site in Italy and one of the most "hit" in the world. ${ }^{10}$

Shortly after launching his blog, Grillo began a "Clean Up Parliament" campaign to protest against the presence of convicted criminals in the legislature. ${ }^{11}$ In fact, criminal conviction in lower courts is not incompatible with holding office in Parliament (although it is for lower-level elected offices), such incompatibility requiring the upholding of a conviction by the Court of Appeals and/or, where there is further appeal, by the Court of Cassation. One controversial political figure who, as the result of such a multi-level process, resigned his status as a deputy on 31 July 2007 was Cesare Previti, long Berlusconi's personal lawyer and a leading legal figure in Fininvest, the financial holding company controlled by Berlusconi's family. Using his blog and a network of Web-organized "Meetup" groups, Grillo mobilized Italian citizens throughout the country to back his campaign, both formally and symbolically, and to tell the corrupt political elites to "Eff off." Thus, on 8 September 2007, dubbed "V-Day" by Grillo, at least 300,000 Italians in towns and cities throughout the country attended rallies and signed three petitions to be presented to Parliament. The extraordinary success of the event suggested that Grillo's blog, combined with nearly 70,000 members of his Meetup links, constitutes a powerful organizational force. ${ }^{12}$

The first of the three petitions for which signatures were collected by Grillo and his "Web friends" would make criminal conviction at any judicial level incompatible with public office. The second would limit to two terms the length of time a politician could serve in Parliament. The 
third would enable voters to select among parliamentary candidates rather than be forced to accept the candidates chosen by party leaders in so-called closed lists. Such petitions require 50,000 signatures to oblige Parliament to consider them, so the collection of 300,000 signatures in just one day had great significance. In comparison, it took the referendum movement most of its three months of allotted time to collect 800,000 signatures. While parliamentary "consideration" need not in practice take up very much of Parliament's time-and in the past has usually taken very little indeed-this time the device has given institutional expression to mass public discontent and exposes Parliament and the political elites to further public disdain if the proposals should be disregarded. The petitions were delivered to the Senate on 14 December, ${ }^{13}$ and the whole affair triggered widespread and vigorous debate as to the extent of the danger that Grillo represented to Italy's institutions. The conservative liberal political scientist, Giovanni Sartori, however, defended both Grillo's actions and the populist figure himself against the accusation of being a dangerous demagogue. ${ }^{14}$

Others have argued that many of Grillo's supporters, far from being anti-political, are not only political but constructively so, seeking to clean up Italian politics and to encourage the participation of citizens in politics by presenting options to the highly compromised, established political parties - or at least seeking to transform the parties. ${ }^{15}$ For 2008, Grillo planned a second V-Day, to be held on 25 April, the national holiday celebrating the Resistance movement and Italy's liberation from Fascism, and the participation in local elections of civic lists backed by himself. To be included in these lists, candidates were required to have no criminal record and could not be a member of any political party. It was doubtful from the outset that such a movement could effectively challenge the electoral grip of the political parties in a strongly polarized society, even at only the local level, and the calling of early parliamentary elections marginalized Grillo's experiment with local politics.

Nevertheless, other signs of the demand for engagement and innovation and evidence of the propensity for mobilization were conspicuous in 2007. These included, most noticeably, the participation in early October of over 3 million voters in the so-called primaries to elect Walter Veltroni as the leader of the new Democratic Party, and the demonstration, organized by the "radical" or traditional left, by up to 1 million people in Rome on 20 October in support of jobs, pensions, health care, and public sector education. The center-right, too, had shown surprising success in mobilizing its electorate en masse in the anti-government demonstration held on December 2006, while in November 2007 Berlusconi organized a series of mobilizations calling 
for the government to resign, which were then turned into a mobilization to support his new party. While these mobilizations can rightly be seen as populist-and Berlusconi, unlike Grillo, can be seen as a dangerous demagogue - there is little doubt that the desire for a simplified politics and more effective government is felt on the right as well as the left. Arguably, then, Italy in 2007 furnished ample evidence of the view that the phenomenon of populism, albeit Janus-faced, is integral to democracy: at one and the same time, it is both potentially dangerous and potentially capable of renovating stale democratic systems. ${ }^{16}$

Grillo's campaign was boosted considerably by the extraordinary success of a book published in May that was written by two leading journalists for Corriere della Sera, Gian Antonio Stella and Sergio Rizzo. Titled La Casta: Così i politici italiani sono diventati intoccabili (The Caste: How Italian Politicians Became Untouchable), the volume is a detailed denunciation of the costs and excesses of Italian politics and of the estimated 600,000 people who make their living from it. The book rapidly became a publishing sensation, selling over a million copies and ending the year as the non-fiction best-seller of 2007. While the authors offered no remedies, and the book provoked little response from the political elite, other than some half-hearted and unconvincing legislative packages to cut "the costs of politics," Grillo's autumn mobilization, in contrast, channeled popular hostility toward the political class into some measure of concrete action and helped galvanize the political establishment.

\section{Responding to the Challenge}

The creation of the Democratic Party, led by Veltroni, and the need clearly felt by Berlusconi to respond by creating a unified center-right promised to reinforce the bipolarization of Italian politics, despite attempts within both left and right to form a more articulated party system structure. Indeed, some saw the popularity of Veltroni, who was identified as the only politician more popular than Grillo in the November 2007 poll, and the sheer political power of Berlusconi, who reasserted his authority over the center-right in the closing weeks of the year, as signifying the development in Italy of "bi-leaderism," with a concomitant marginalization of other leaders and minor political forces around them. Thus, the crisis into which Italy's political system had been tipping since the 2006 election-which was identified by those promoting the referendum campaign for electoral reform and by a succession of leading political and economic figures as extremely serious and, indeed, systemic — did appear to be bringing about political 
developments that promised to contribute significantly to concluding the so-called transition.

Veltroni and the new Democratic Party claimed to offer Italy the political innovation that Italian society has arguably long been seeking: a cohesive, reformist, modernizing political force that is capable of obtaining a parliamentary majority in its own right, or, more realistically, that aims to control the government's formation and to survive in office while dominating the public policy agenda. Such a partywere it to result and successfully to persist, consolidating itself and a moderate bipolar party system-would meet Gordon Smith's criteria for defining so-called people's parties, the significance of which is their ability to provide both representation and effective, moderate government and hence to stabilize their polities. ${ }^{17}$ Were Berlusconi also able to achieve some similar integration of the center-right, increasing its ability to provide more cohesive, and thus more effective, government, one could conclude that the Italian "transition" had truly come to an end. But that is hypothesis and conjecture. At the end of 2007, doubts remained as to how successful both of these major political innovations would be-or even could be-without supportive institutional reform of the electoral system and of parliamentary regulations.

\section{Notes}

1. L. Morlino and M. Tarchi, "La società insoddisfatta e i suoi nemici: I partiti nella crisi italiana," in Partiti e caso italiano, ed. Morlino and Tarchi (Bologna: Il Mulino, 2006), 207-243.

2. See A. Mastropaolo, "Eziologia di una crisi di fine millennio, come è stata costruita le crisi italiana," Teoria politica 15, no. 2-3 (1999): 247-280, on the role of the (inaccurate) public discourse of "partyocracy" in bringing down the "First Republic." See also A. Mastropaolo, Antipolitica: Alle origini della crisi italiana (Naples: L'Ancora, 2006).

3. Morlino and Tarchi, "La società insoddisfatta."

4. On the difference between strong and weak forms of bipolarism, see R. D’Alimonte, "Il 'bipolarismo forte' dei grandi Stati europei," Il Sole 24 Ore, 27 November 2007. See also G. Sartori, "Il bipolarismo non si uccide," Corriere della Sera, 21 November 2007.

5. I. Diamanti, "Gli italiani prigionieri della sfiducia," La Repubblica, 13 December 2007, and I. Diamanti, "L'Italia? Insicura, sfiduciata e stufa del vecchio che avanza," Il venerdi di Repubblica, 14 December 2007; F. Bordignon, “Democrazia: Un terzo degli italiani ne può fare a meno. Ma nel mirino ci sono sporatutto i partiti," Il venerdi di Repubblica, 14 December 2007. 
6. For Europe, see http://ec.europa.eu/public_opinion/archives/ebs/ebs_273_ en.pdf. For Italy, see http://ec.europa.eu/public_opinion/archives/ebs/ ebs_273_fiche_it.pdf. For the UK, see http://ec.europa.eu/public_opinion/ archives/ebs/ebs_273_fiche_uk.pdf. In fact, "anti-party" sentiment and "disaffection” toward the actual practice of democratic politics have been widely observed for many years now. See, for example, T. Poguntke and S. Scarrow, "The Politics of Anti-party Sentiment: Introduction," European Journal of Political Research 29, no. 3 (1996): 257-262; G. Stoker, Why Politics Matters: Making Democracy Work (Basingstoke: Palgrave Macmillan, 2006).

7. R. Mannheimer, Corriere della Sera, 30 December 2007.

8. See http://www.time.com/time/europe/hero2005/grillo.html.

9. See http://premiowww.ilsole24ore.com/classifiche.php (accessed 6 February 2008).

10. See http://it.blogbabel.com/metrics/ and http://technorati.com/pop/blogs/.

11. Grillo took out a full-page advertisement in the International Herald Tribune on 27 November 2005 to back his campaign. See http://www.beppegrillo .it/immagini/beppe_ht.pdf.

12. See the map identifying 65,826 members in 472 Meetups in 27 countries at http://beppegrillo.meetup.com/about/?gmap $=1$.

13. La Repubblica, 14 December 2007, http://www.repubblica.it/2007/11/sezioni/ politica/grillo-contro-napolitano/grillo-firme/grillo-firme.html.

14. G. Sartori, "La terra trema sotto la casta," Corriere della Sera, 19 September 2007; G. Sartori, "Il revival del populismo," Corriere della Sera, 2 October 2007.

15. I am grateful to Alfio Mastropaolo for sharing his views on Grillo, although the presentation here differs significantly from his.

16. See, in particular, M. Canovan, "Trust the People! Populism and the Two Faces of Democracy," Political Studies 47, no. 1 (1999): 2-16.

17. G. Smith, “Core Persistence: Change and the 'People's Party,'” West European Politics 12, no. 4 (1999): 157-168. 